\section{IPA claims harrassment}

\section{London}

THE Soviet Union's new Independent Psychiatrists' Association (IPA) has appealed to psychiatric associations abroad for support following a burglary which it is convinced was deliberate harassment by the Soviet security police. The IPA was founded earlier this year. Its members, from all parts of the Soviet Union, consider that, the Soviet psychiatric establishment is still dominated by those who, during the Brezhnev era, made Soviet psychiatry a byword for political repression and abuse of human rights.

IPA maintains that, in spite of public denials and the visit to Soviet mental hospitals of a "verification" team from the United States, persons of sound mind but inconvenient views are still being committed to Soviet psychiatric hospitals.During the past few months, they have been compiling an archive of known cases as well as offering professional help to patients who, for various reasons, do not wish to seek help through the state system.

Their records, together with correspondence with psychiatrists abroad, were housed in the apartment of one of the association members. A few weeks ago, when the householder was absent for only two hours, the apartment was broken into and the files removed. The break-in, says the IPA, was obviously not the work of an ordinary burglar, since valuables were left untouched.

In an open letter addressed to psychiatric associations throughout the world, Aleksandr Ogorodnikov, a human rights activist and founder-member of the IPA, says that harassment of this kind will not deter IPA, but its members are afraid that seizure of the archives could bring harm to those who have asked IPA for help.

The position of the IPA, Ogorodnikov wrote, would be considerably strengthened if it could become a member of the World Psychiatric Association. Shortly after its foundation, IPA submitted an application for membership, to be considered at the next General Assembly of the WPA, in Athens next week. But the WPA secretariat has refused to process this application, on the grounds that it should have been submitted a full year in advance, when IPA did not exist.

The WPA executive shows signs of proving far less rule-bound in the case of the official Soviet psychiatric society. That organization resigned from the WPA in 1983 to forestall several motions on the agenda for its expulsion. The establishment psychiatrists will also be seeking readmission to the WPA next week although in its present form that body, too, has existed for less than a year.

Vera Rich

\section{Vlenna}

SPEAKING candidly at the 33rd general conference of the International Atomic Energy Agency (IAEA) last week in Vienna, Soviet representatives admitted that the Soviet Union faces serious problems in the continued expansion of its nuclear programme. But, while also announcing a strong commitment to protecting the environment, the Soviet government intends to persist with plans for more nuclear power.

The problem is familiar to Western planners: the Soviet Union would like to increase its power generation capacity by building both nuclear and non-nuclear plants. But nuclear plants run into public opposition, while clean-burning fossil fuel plants are expensive.

With the Chernobyl accident still fresh in the memory, no new Chernobyl-type reactors will be built. Nevertheless, according to Chairman A. N. Protsenko of the State Commitee on the Utilization of Atomic Energy, nuclear generating capacity will be doubled by the year 2000 , increasing the proportion of Soviet electricity derived from nuclear power from 13 to 15 or 16 per cent.

But "public opinion affects the rate of construction," he said. Protsenko admitted that, while other countries had carried out effective public relations campaigns to make people aware of safety measures at nuclear power plants, "we did not". He attributes what he sees as a "negative attitude" towards nuclear power in the Soviet Union to a "lack of awareness", and revealed that the Soviet Union had been taking lessons from France in how to convince people that nuclear power is safe. A Soviet team visited France one month ago to observe French public relations efforts, and made films for Soviet television.

Slower growth in nuclear capacity has led to plans for more fossil fuel power stations, but the cost penalty of 60 to 70 per cent incurred by equipping a coal-fired power station with scrubbers to remove sulphur and other pollutants has persuaded the Soviet Union to construct its new - and unclean - plants in sparsely populated regions such as the Ural Mountains. This is a "temporary measure," Protsenko added.

Environmentalism has apparently seeped into official Soviet thinking: Protsenko cited a figure of 50,000 million rubles per year $(\$ 79,400$ million at the official exchange rate) for the total cost of damage due to environmental pollution in the Soviet Union. One quarter of this is attributed to power generation. Protsenko expects the Supreme Soviet to devote more money to the environment in the 1990 budget. When asked if this would not be difficult in light of the country's prob- lems in providing items such as basic foodstuffs for its population, he said that it is equally important to provide "foodstuffs and clean air". But Soviet delay in cleaning up the air was criticized by other countries. Rolf Annerberg of the Swedish Ministry of Environment and Energy said that transboundary pollution contributes 75 per cent of the air pollution in Sweden, and called on the Soviets to improve the efficiency of their existing plants instead of building new ones. But Annerberg welcomed the Soviet willingness to discuss the issue. "Before, it was impossible to have anyone say there was a problem", he said.

A number of other Soviet announcements at the conference met with the same mixture of pleasure and scepticism. The Soviet offer to site an international research centre on the consequences of nuclear accidents and nuclear accident management at Chernobyl was repeated. The idea had originally been mentioned to the IAEA board of governors in June.

In a closed meeting, representatives of the IAEA member states that have nuclear power showed some interest in the proposal, although they raised a number of questions that the Soviets chose not to answer. For instance, they asked what research the Soviets had already done at Chernobyl and what purpose an IAEAsponsored agreement would serve in gaining international access to the site. Although no public response was given, the Soviets were thought to have offered to share results from their investigations and access to waste materials from both the 1986 Chernobyl accident and the 1957 nuclear explosion at Kasli in the Urals (see Nature 339, 572; 1989).

The Soviet offer will now be considered by member states before any official response is made. The issue is set to be discussed again at the February board of governors meeting.

IAEA director general Hans Blix of Sweden, whose election to a third fouryear term was confirmed by the conference, said that the Soviet Union had also offered to provide a site for an international research project in waste disposal, possibly in the Chernobyl area. But Soviet representatives did not elaborate.

Long-running IAEA issues such as South African and Israeli nuclear capabilities took second place at this year's conference.

South Africa once again promised to consider signing the nuclear non-proliferation treaty (NPT), and will meet with the United States, the Soviet Union and the United Kingdom in December to discuss the matter. The conference postponed for another year a resolution to bar South Africa from the IAEA.

Steven Dickman 